\title{
ЕНДОГЕННА ІНТОКСИКАЦІЯ В ЩУРІВ 3 ЕКСПЕРИМЕНТАЛЬНИМ КАНЦЕРОГЕНЕЗОМ ПІСЛЯ ЗАСТОСУВАННЯ ЦИТОСТАТИКА НА ТЛІ СОРБЦІЙНОЇ ТЕРАПІЇ
}

Вступ. Щороку кількість онкологічних хворих на колоректальний рак зростає. Тяжкість стану хворих досить часто зумовлена гіперфункцією активних фрорм оксигену з подальшим порушенням антиоксидантного захисту організму. Тому важливим є вивчення ефективності дії цитостатика на тлі ентеросорбційної терапії за умов ендогенної інтоксикації.

Мета дослідження - оцінити ефективність використання цитостатика "Вінкристин" на тлі ентеросорбційної терапії за умов оксидативного стресу в організмі щурів, уражених 1,2-диметилгідразином.

Методи дослідження. Експеримент виконано на білих щурах-самцях, яким моделювали рак товстої кишки шляхом щотижневого підшкірного введення 1,2-диметилгідразину в дозі 7,2 мг/кг маси тіла протягом 30-ти тижнів. Ентеросорбент АУТ вводили інтрагастрально щоденно впродовж 21-го дня після моделювання канчерогенезу в дозі 1 мл завису (що відповідає 0,2 г чистої маси препарату) на 100 г маси тіла тварини. Цитостатик "Вінкристин" вводили тваринам з індукованим канцерогенезом внутрішньошлунково щоденно протягом 14-ти днів у дозі 0,23 мг/ка маси тіла після 21-денної детоксикаційної терапії. Розвиток оксидативного стресу вивчали за активністю окисної модифрікації протеїнів, концентрацією продуктів пероксидного окиснення ліпідів, активністю супероксиддисмутази і каталази.

Результати й обговорення. Отримані результати дослідження свідчать про те, що введення 1,2-диметилгідразину протягом 30-ти тижнів сприяло розвитку оксидативного стресу. В експериментальних тварин порушувався про-антиоксидантний баланс, що супроводжувалося зниженням активності антиоксидантної системи. Застосування ентеросорбенту АУТ сприяло нормалізації цих показників, а проведена цитостатична терапія незначно вплинула на перебіг окиснювальних прочесів в організмі піддослідних тварин.

Висновок. Отримані результати вказують на відсутність вираженого побічного ефекту цитостатика "Вінкристин" та підтверджують позитивну динаміку використання детоксикаційної терапії ентеросорбентом АУТ під час прогресуючого розвитку оксидативного стресу за умов змодельованого канцерогенезу.

КЛЮЧОВІ СЛОВА: оксидативний стрес; антиоксидантна система; 1,2-диметилгідразин; ентеросорбент АУТ; цитостатик "Вінкристин".

ВСТУП. Всесвітня організація охорони здоров'я щороку оприлюднює прогресуючу статистику зростання кількості онкологічних захворювань. За даними Міжнародного агентства 3 досліджень раку (IARC/IARS, Ліон), кількість онкохворих пацієнтів у всьому світі у 2018 р. становила понад 18 мільйонів [1]. Тому вивчення проблеми онкологічного захворювання і надалі залишається актуальним питанням наукових досліджень.

Учені відмітили, що морфологічні та гістологічні зміни, які виникають у товстій кишці гризунів (с О. І. Качур, Л. С. Фіра, П. Г. Лихацький, 2020. унаслідок ураження 1,2-диметилгідразином (1,2-ДМГ), максимально точно імітують процеси, що мають місце у людському організмі в процесі розвитку онкопроцесу [2]. Саме тому 1,2-диметилгідразинова модель слугує ідеальною експериментальною моделлю для хіміопрофілактичних досліджень. Ця хімічна речовина в дозозалежний спосіб викликає індукування пухлинного генезу в експериментальних моделях гризунів. Відомо, що процес індукування раку товстої кишки супроводжується надмірною генерацією активних фрорм оксигену (АФО), натомість детоксикаційні можливості організму 
зменшуються. Тривала інадмірна генерація АФО сприяє розвитку оксидативного стресу, що активує вільнорадикальні процеси та пероксидне окиснення ліпідів [3].

У сучасній медицині метод ентеросорбції використовують у комплексі лікувальної терапії для зменшення проявів оксидативного стресу. Аналізуючи результати багаторічного вивчення механізмів дії ентеросорбентів, ми прийшли до висновку, що на особливу увагу заслуговують вуглецеві сорбенти. До них належить ентеросорбент АУТ, що проявляє значні детоксикаційні властивості, з питомою поверхнею пор близько 2000-2500 м²/г [4, 5].

Лікування онкологічних хворих передбачає комплекс методів, до яких належить хіміотерапія. Науково доведено позитивну цитостатичну активність алкалоїдів барвінку рожевого. Екстракти листя, квітки та кореня цієї рослини містять понад 400 алкалоїдів, затверджених як протипухлинний засіб. Їх широко використовують у багатьох хіміотерапевтичних схемах при найрізноманітніших ракових захворюваннях [6].

Мета дослідження - оцінити ефективність використання цитостатика "Вінкристин" на тлі ентеросорбційної терапії за умов оксидативного стресу в організмі щурів, уражених 1,2-диметилгідразином.

МЕТОДИ ДОСЛІДЖЕННЯ. Експеримент виконано на 77-ми лабораторних білих щурахсамцях, яких утримували на стандартному раціоні віварію Тернопільського національного медичного університету імені І. Я. Горбачевського МОЗ України. Маса їх тіла становила 180220 г. Усі маніпуляції з експериментальними тваринами проводили, дотримуючись правил Європейської конвенції про захист хребетних тварин, що використовуються для дослідних та інших наукових цілей, а також відповідно до Науково-практичних рекомендацій з утримання лабораторних тварин та роботи з ними [7].

Щурів рандомізували на групи: 1-ша - контрольна, тварини якої отримували ізотонічний розчин натрію хлориду; 2-га - тварини, уражені 1,2-ДМГ; 3-тя - тварини, уражені 1,2-ДМГ, які після 30-тижневого введення канцерогену одержували ентеросорбент АУТ упродовж 21-го дня; 4-та-тварини, яким після виконання ентеросорбційної терапії вводили цитостатичний препарат "Вінкристин" протягом 14-ти днів.

Канцерогенез моделювали шляхом введення несиметричного 1,2-диметилгідразин гідрохлориду (фірми "SIGMA-ALDRICH CHEMIE", виробництва Японії), попередньо розведеного ізотонічним розчином натрію хлориду. 1,2-Диметилгідразин вводили підшкірно в міжлопаткову ділянку в дозі 7,2 мг/кг (з розрахунку на діючу речовину) 1 раз на тиждень протягом 30-ти тижнів відповідно до маси тіла тварини [8].

Сорбуючий препарат АУТ вводили інтрагастрально щоденно впродовж 21-го дня після моделювання канцерогенезу. Добова доза сорбенту - 1 мл завису (що відповідає 0,2 г чистої маси препарату) на 100 г маси тіла тварини.

Вінкристин, як компонент цитостатичної терапії, вводили внутрішньошлунково щоденно в дозі 0,23 мг/кг маси тіла тварини протягом 14-ти днів, починаючи відразу після 7-місячного моделювання онкопроцесу та 21-денної ентеросорбційної терапії. Дозу цитостатика підбирали, користуючись інструкцією до застосування препарату і враховуючи видову чутливість тварин (перерахунок здійснювали за Ю. Р. Риболовлєвим, 1979) [9].

Кожного місяця від початку дослідження уражених тварин виводили з експерименту шляхом евтаназії під тіопенталовим наркозом. Для дослідження брали сироватку крові щурів та гомогенати печінки.

Інтенсивність процесів окисної модифрікації протеїнів (ОМП) визначали за методикою R. Levine шляхом реєстрації оптичної щільності аліфатичних альдегідо- та кетодинітрофенілгідразонів основного і нейтрального характеру 2,4-динітрофенілгідразонів [10]. Вміст ТБК-активних продуктів у сироватці крові та печінці досліджували в реакції з тіобарбітуровою кислотою [11]. Стан антиоксидантної системи вивчали за активністю каталази [12] і супероксиддисмутази (СОД) [13].

Для статистичної обробки результатів використовували параметричні й непараметричні методи оцінки отриманих даних. Для всіх показників розраховували середню арифрметичну величину вибірки (М) та похибку середньої арифметичної величини (m). Достовірність різниці значень між незалежними кількісними величинами встановлювали при нормальному розподілі за критерієм Стьюдента, в інших випадках - за допомогою критерію Манна - Уїтні. Різницю між величинами вважали вірогідною при величині $p \leq 0,05$ [14].

РЕЗУЛЬТАТИЙ ОБГОВОРЕННЯ. ВіДОМО, ЩО моделювання раку товстої кишки супроводжується надмірною генерацією АФО, натомість детоксикаційні можливості організму зменшуються. Тривала і надмірна генерація АФО сприяє розвитку оксидативного стресу, що активує вільнорадикальні процеси та пероксидне окиснення ліпідів [15].

Науково доведено, що первинні продукти пероксидного окиснення ліпідів (гідропероксиди 
ліпідів) є нестійкими речовинами, які легко руйнуються з утворенням стабільніших вторинних продуктів. Серед вторинних продуктів найбільш відомий малоновий діальдегід, вміст якого визначають у реакції з тіобарбітуровою кислотою $[16,17]$.

Виявлено вірогідне збільшення вмісту ТБК-активних продуктів уже в 1-й місяць ураження щурів: у сироватці крові цей показник підвищився на $144 \%$, у печінці - на $190 \%$ порівняно 3 контрольною групою (рис. 1).

На 7-й місяць дослідження цей показник підвищився порівняно 3 контрольною групою: в сироватці крові - на 610 \%, у печінці - на $355 \%$. На тлі застосування ентеросорбенту АУТ (21 день) вміст ТБК-активних продуктів у сироватці крові був нижчим на $241 \%$, у печінці - на $145 \%$ (рис. 2).

Аналізуючи отримані результати після проведення цитостатичної терапії, ми зафріксували вірогідне зниження цього показника в сироватці крові (на 214 \%) та печінці (на 133 \%) щурів 3 індукованою карциномою товстої кишки і після 21-денного приймання ентеросорбенту АУТ відносно групи тварин, уражених 1,2-ДМГ протягом 7-ми місяців.
Відомо, що за умов експериментального канцерогенезу товстої кишки в щурів збільшується вміст ТБК-активних продуктів та, як наслідок, зменшується активність ензимів антиоксидантної системи захисту - СОД і каталази [18].

Підтвердженням є зниження активності СОД і зростання ТБК-активних продуктів. Встановлено вірогідне зменшення активності СОД за умов індукованого канцерогенезу, починаючи з 4-го місяця ураження (на 31 \%) (рис. 3). Цей показник знижувався і в наступні місяці експерименту (7-й місяць - на 43 \%). Зменшення активності СОД може свідчити про збільшення в клітині концентрації гідроген пероксиду та інактивацію каталази, що розщеплює гідроген пероксид [19].

Використання ентеросорбенту АУТ позитивно вплинуло на показники ензиматичної ланки антиоксидантної системи. Після його введення в уражений організм активність СОД на 21-й день застосування ентеросорбенту збільшилася на $28 \%$. Проведення цитостатичної терапії призвело до підвищення активності цього ензиму в печінці на 21 \% відносно групи тварин, яким не виконували корекції ентеросорбентом.

Під час моделювання канцерогенезу активність каталази в сироватці крові уражених щурів

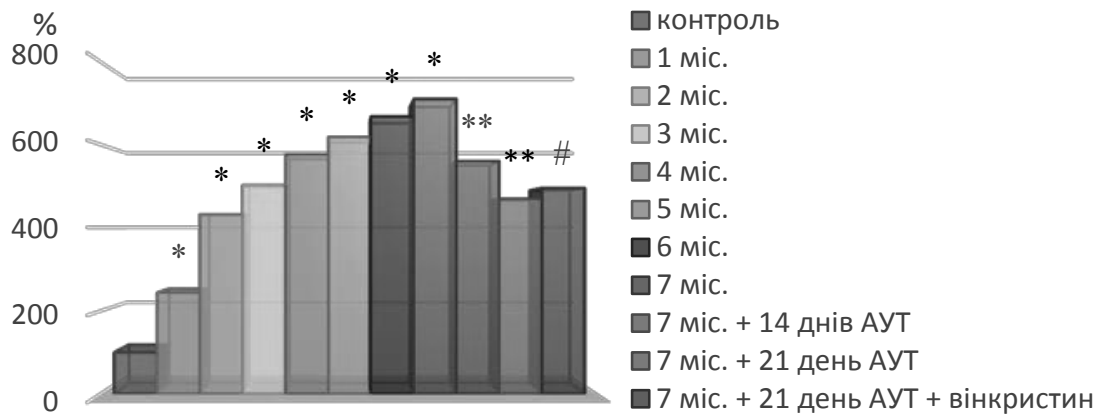

Рис. 1. Вміст ТБК-активних продуктів у сироватці крові щурів у динаміці ураження 1,2-диметилгідразином та після застосування ентеросорбенту АУТ і цитостатика "Вінкристин", \%.

Примітка. Тут і на рисунках 2, 3, у таблицях 1, 2: * - вірогідні зміни між показниками тварин контрольної групи та щурів, уражених 1,2-диметилгідразином; *夫 - вірогідні зміни між показниками тварин, уражених канцерогеном, і щурів, які одержували ентеросорбент; *** - вірогідні зміни між показниками тварин, уражених канцерогеном, після ентеросорбційної терапії (21 день) та щурів, які отримували цитостатик (14 днів); \# - вірогідні зміни між показниками тварин, уражених канцерогеном (7-й місяць), і щурів, які одержували цитостатик (14 днів) на тлі ентеросорбційної терапії (21 день).

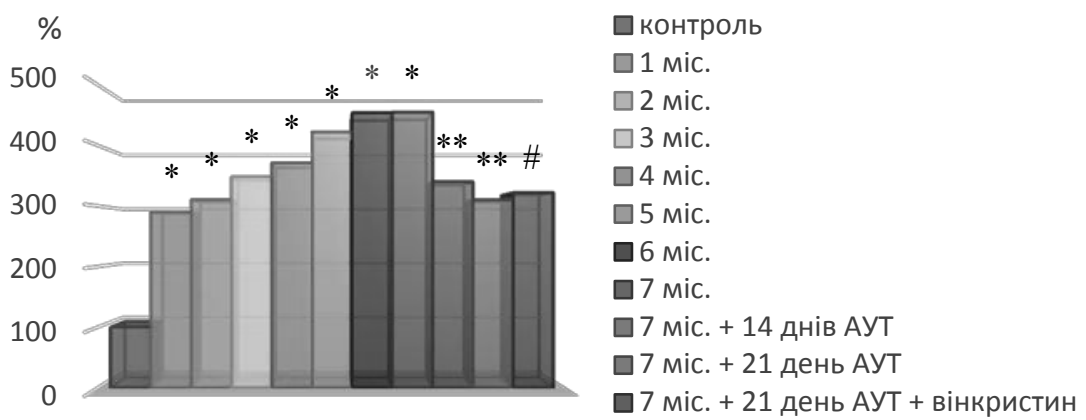

Рис. 2. Вміст ТБК-активних продуктів у печінці щурів у динаміці ураження 1,2-диметилгідразином та після застосування ентеросорбенту АУТ і цитостатика "Вінкристин”, \%. 


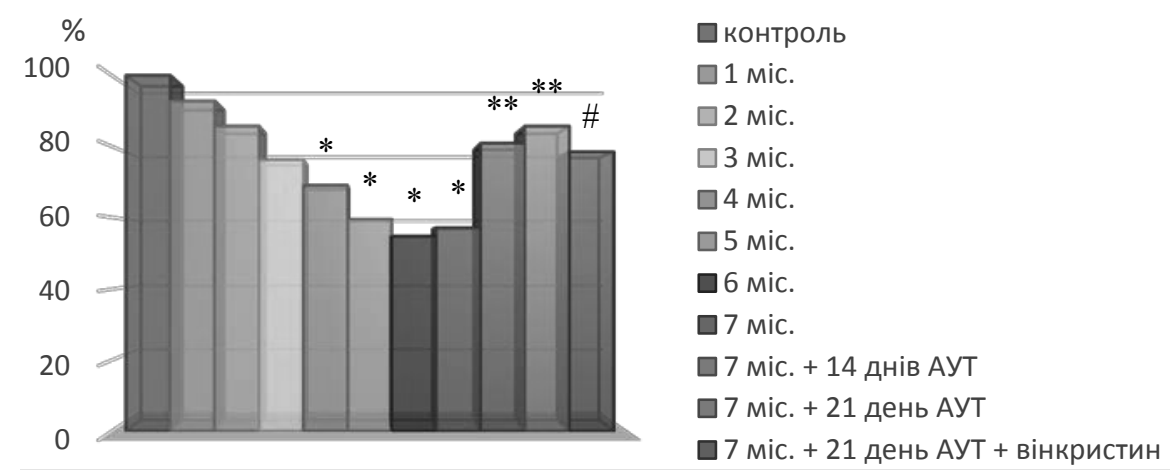

Рис. 3. Активність супероксиддисмутази в печінці щурів за умов модельованого канцерогенезу та на тлі застосування ентеросорбенту АУТ і цитостатика "Вінкристин", \%.

вірогідно $(p \leq 0,05)$ зменшилася на 3-й місяць експерименту (на $38 \%$ ) та продовжувала знижуватися протягом наступних місяців ураження (7-й місяць - на 69 \%) (табл. 1).

Аналогічне зменшення активності досліджуваного ензиму виявлено в печінці уражених щурів. Починаючи з 2-го місяця введення 1,2-ДМГ, цей показник знизився на $27 \%$, на 7-й місяць моделювання раку товстої кишки активність каталази зменшилася на $72 \%$ відносно контрольної групи.

Доцільним було дослідити активність цього ензиму в сироватці крові та печінці щурів, уражених 1,2-ДМГ, після сорбційної терапії препаратом АУТ. Отримані результати вказують на підвищення активності каталази в печінці та сироватці крові експериментальних тварин під впливом 21-денної дії ентеросорбенту (на 23 і $18 \%$ відповідно). Однак на 14-й день введення цитостатика "Вінкристин" активність каталази в сироватці крові піддослідних тварин знизилася на $12 \%$, у печінці - на $14 \%$ порівняно зі щурами, яким не виконували детоксикаційної корекції.

Маркером раннього розвитку оксидативного стресу $є$ окисна модифрікація протеїнів, що супроводжується їх денатурацією, утворенням амінокислотних радикалів, які далі вступають у вторинну взаємодію із сусідніми амінокислотними залишками [20]. Усі ці процеси призводять до втрати протеїнами їх біологічної активності й порушення обміну речовин. Крім того, негативний ефект ОМП пов'язують із тим, що вони $\epsilon$ джерелом вільних радикалів, які виснажують запаси клітинних антиоксидантів [21].

Ступінь окисної модифрікації протеїнів оцінювали за рівнем кето- й альдегідопохідних нейтрального $\left(\mathrm{OM} \Pi_{370}\right)$ та основного $\left(\mathrm{OM} \Pi_{430}\right)$ характеру (табл. 2).

Введення в організм тварин 1,2-ДМГ призводило до зростання вмісту ОМБ ${ }_{370}$ у сироватці крові й печінці протягом усього дослідження. Так, у 1-й місяць експерименту вміст ОМП ${ }_{370}$ у сироватці крові й печінці уражених щурів вірогідно підвищився у 2,3 та 1,4 раза відповідно $(p \leq 0,05)$ порівняно 3 тваринами контрольної групи, на 7-й місяць дослідження цей показник збільшився порівняно $з$ неураженими щурами: в сироватці крові - у 5,4 раза, в печінці - у 2,7 раза.

Схожу динаміку підвищення показників альдегідо- і кетопохідних основного характеру $\left(О \Pi_{430}\right)$ виявлено в сироватці крові й печінці уражених щурів протягом усього експерименту: в 1-й місяць експерименту в сироватці крові вони зросли в 1,3 раза, в печінці - в 1,5 раза порівня-

Таблиця 1 - Активність каталази в сироватці крові (мккат/л) та печінці (мккат/кг) щурів, уражених 1,2-диметилгідразином, та після застосування ентеросорбенту АУТ

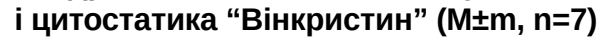


Таблиця 2 - Вміст продуктів окисної модифікації протеїнів у сироватці крові й печінці щурів (мкмоль/г протеїну) в динаміці ураження 1,2-диметилгідразином

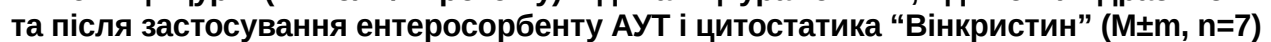

\begin{tabular}{|c|c|c|c|c|}
\hline \multirow{2}{*}{$\begin{array}{l}\text { Група тварин/ } \\
\text { термін ураження }\end{array}$} & \multicolumn{2}{|c|}{$\mathrm{OMM}_{370}$} & \multicolumn{2}{|c|}{$\mathrm{OM \Pi}_{430}$} \\
\hline & сироватка крові & печінка & сироватка крові & печінка \\
\hline Контрольна & $0,15 \pm 0,01$ & $0,29 \pm 0,02$ & $0,30 \pm 0,02$ & $0,38 \pm 0,02$ \\
\hline 1-й місяць & $0,34 \pm 0,02^{*}$ & $0,41 \pm 0,02^{\star}$ & $0,39 \pm 0,02^{*}$ & $0,56 \pm 0,04^{\star}$ \\
\hline 2-й місяць & $0,47 \pm 0,03^{*}$ & $0,47 \pm 0,03^{*}$ & $0,49 \pm 0,02^{*}$ & $0,64 \pm 0,04^{\star}$ \\
\hline 3-й місяць & $0,51 \pm 0,04^{*}$ & $0,60 \pm 0,04^{\star}$ & $0,57 \pm 0,04^{*}$ & $0,68 \pm 0,04^{*}$ \\
\hline 4-й місяць & $0,59 \pm 0,04^{*}$ & $0,68 \pm 0,04^{*}$ & $0,64 \pm 0,05^{*}$ & $0,73 \pm 0,05^{*}$ \\
\hline 5-й місяць & $0,68 \pm 0,05^{\star}$ & $0,70 \pm 0,05^{\star}$ & $0,74 \pm 0,05^{\star}$ & $0,80 \pm 0,06^{\star}$ \\
\hline 6-й місяць & $0,74 \pm 0,05^{*}$ & $0,72 \pm 0,06^{\star}$ & $0,80 \pm 0,05^{*}$ & $0,83 \pm 0,06^{*}$ \\
\hline 7-й місяць & $0,81 \pm 0,06^{*}$ & $0,78 \pm 0,06^{\star}$ & $0,86 \pm 0,06^{*}$ & $0,91 \pm 0,08^{*}$ \\
\hline 1,2-ДМГ + АУТ (14 днів) & $0,59 \pm 0,04^{\star \star}$ & $0,62 \pm 0,05$ & $0,71 \pm 0,06$ & $0,77 \pm 0,05$ \\
\hline 1,2-ДМГ + АУТ (21 день) & $0,51 \pm 0,03^{\star \star}$ & $0,54 \pm 0,03^{\star \star}$ & $0,56 \pm 0,05^{\star \star}$ & $0,70 \pm 0,04^{\star \star}$ \\
\hline $\begin{array}{l}7 \text { місяців ураження 1,2-ДМГ + АУТ } \\
\text { (21 день) + вінкристин (14 днів) }\end{array}$ & $0,52 \pm 0,03^{\#}$ & $0,55 \pm 0,02^{\#}$ & $0,60 \pm 0,04^{\#}$ & $0,72 \pm 0,04$ \\
\hline
\end{tabular}

но з відповідними показниками тварин контрольної групи, на 7-й місяць дослідження - у 2,9 та 2,4 раза відповідно.

Для пригнічення розвитку оксидативного стресу, зокрема процесів окиснювальної модифрікації протеїнів, у тварин з аденокарциномою товстої кишки ми використали ентеросорбент АУТ. Застосування цього коригувального чинника призвело до вірогідного зниження $(p \leq 0,05)$ вмісту ОМП ${ }_{370}$ та ОМП ${ }_{430}$ у сироватці крові й печінці тварин, уражених 1,2-ДМГ. На 21-й день дослідження вміст ОМП печінці щурів зменшився після використання ентеросорбенту на 200 і 83 \% відповідно, ОМП ${ }_{430}$ на 100 та 55 \% порівняно з показниками уражених тварин.

Після проведення детоксикаційної терапії в одній із груп тварин було використано цитостатик "Вінкристин". Отримані результати вказують на незначне підвищення вмісту продуктів ОМП нейтрального та основного характеру як у сироватці крові, так і в печінці після застосування цитостатика в щурів з модельованим канцерогенезом на тлі сорбційної терапії (21 день). щодо групи тварин з канцерогенезом, які не отримували ентеросорбенту, то вміст ОМП після проведення ентеросорбційної і цитостатичної корекції був вірогідно нижчим $(p \leq 0,05)$.

СПИСОК ЛІТЕРАТУРИ

1. Bray F. Global cancer statistics 2018: Globocan estimates of incidence and mortality worldwide for 36 cancers in 185 countries / F. Bray, J. Ferlay, I. Soerjomataram [et al.] // CA Cancer J. Clin. -2018. - No. 68. P. 394-424.

2. Arigesavan K. Carvacrol exhibits anti-oxidant and anti-inflammatory effects against 1, 2-dimethyl hydrazine
Отже, встановлено, що ураження експериментальних тварин 1,2-ДМГ протягом 7-ми місяців призводить до дисбалансу антиоксидантної системи організму, активації процесів пероксидного окиснення ліпідів та окисної модифікації протеїнів. Виявлено відсутність вираженого побічного ефекту цитостатика "Вінкристин", що підтверджує позитивну динаміку використання детоксикаційної терапії сорбентом АУТ під час прогресуючого розвитку оксидативного стресу за умов змодельованого онкопроцесу.

ВИСНОВКИ. 1. За умов змодельованого канцерогенезу товстої кишки розвивається оксидативний стрес, на що вказує зростання вмісту продуктів ліпопероксидації та окисної модифікації протеїнів протягом експерименту.

2. Використання ентеросорбенту АУТ призводить до зниження активності вільнорадикальних процесів та відновлення показників ензиматичної ланки антиоксидантної системи.

3. Цитостатичний препарат рослинного походження "Вінкристин” має позитивний вплив на активність окиснювальних процесів у щурів за умов експериментального канцерогенезу і не проявляє виражених побічних ефектів, що, очевидно, зумовлено попереднім проведенням ентеросорбційної терапії. 
O. O. Hamiza, M. U. Rehman, M. Tahir [et al.] // Asian Pacific Journal of Cancer Prevention. - 2012. No. 13 (9). - P. 4393-402.

4. Biomedical applications of carbon adsorbents / S. V. Mikhalovsky, S. R. Sandeman, C. A. Howell [et al.] // In Novel Carbon Adsorbents. - 2012. - No. 21. - P. 639669.

5. Carbon adsorbents in oncology: achievements and perspectives / V. G. Nikolaev, L. A. Sakhno, E. A. Snezhkova [et al.] // Exp. Oncol. - 2011. - No. 33. P. 2-8.

6. Aspects of Vincristine-induced neuropathy in hematologic malignancies: A systematic review/M. L. Madsen, H. Due, N. Ejskjær [et al.] // Cancer Chemother Pharmacol. - 2019. - No. 84. - P. 471-485.

7. Науково-практичні рекомендації з утримання лабораторних тварин та роботи з ними / Ю. М. Кожем'якін, О. С. Хромов, М. А. Філоненко, Г. А. Сайфретдінова. - К. : Авіцена, 2002. - С. 156.

8. Дерягина В. П. Экспериментальное изучение действия Lentinus Edodes (Шиитаке) на рост опухоли у мышей на моделях трансплантационного и химического канцерогенеза/В.П.Дерягина, Н. И. Рыжова, А. Н. Разин // Росс. онкол. журн. - 2009. - № 1. C. 33-38.

9. Рыболовлев Ю. Р. Дозирование веществ для млекопитающих по константам биологической активности / Ю. Р. Рыболовлев, Р. С. Рыболовлев // Докл. АН СССР. - 1979. - 247, № 6. - С. 1513-1516.

10. Дубинина Е. Е. Окислительная модифрикация протеинов, ее роль при патологических состояниях I Е. Е. Дубинина, А. В. Пустыгина // Укр. біохім. журн. 2008. - 80, № 6. - C. 5-18.

11. Лущак В. І. Показники оксидативного стресу. Тіобарбітурактивні продукти і карбонільні групи білків / В. І. Лущак, Т. В. Багнюкова, О. В. Лущак // Укр. біохім. журн. - 2004. - 76, № 6. - С. 136-141.

12. Королюк М. А. Метод определения активности каталазы / М. А. Королюк, Л. И. Иванова, И. Г. Майорова // Лаб. дело. - 1988. - № 1. - С. 16-19.
13. Чевари С. Роль супероксиддисмутазы в окислительных процессах клетки и метод определения ее в биологических материалах / С. Чевари, И. Чаба, И. Секей // Лаб. дело. - 1985. - № 11. - С. 678-681.

14. Okeh U. Statistical problems in medical research / U. Okeh // East. Afr. J. Public. Health. - 2009. - 6, Issue 1. - P. 1-7.

15. Марущак М. І. Роль активних фрорм кисню у розвитку та прогресуванні гострого ураження легень в експерименті / М. І. Марущак // Мед. хімія. - 2012. № 1 (50). - C. 104-108.

16. Perše M. The dimethylhydrazine induced colorectal tumours in rat - experimental colorectal carcinogenesis / M. Perše, A. Cerar // Radiology and Oncology. 2005. - No. 21 (3). - P. 61-70.

17. Зинь А. Прооксидантно-антиоксидантний гомеостаз і мембранний транспорт у живих організмах / А. Зинь // Вісн. Львів. ун-ту. - 2012. - Вип. 60. - С. 2139.

18. Thymoquinone the Nigella sativa bioactive compound, prevents circulatory oxidative stress caused by 1,2-dimethylhydrazine in erythrocyte during colon postinitiation carcinogenesis / H. J. Harzallah, R. Grayaa, W. Kharoubi [et al.] // Oxid. Med. Cell Longev. - 2012. P. 1-6.

19. Amelioration of 1,2 dimethylhydrazine (DMH) induced colon oxidative stress, inflammation and tumor promotion response by tannic acid in wistar rats / O. O. Hamiza, M. U. Rehman, M. Tahir [et al.] // Asian Pacific Journal of Cancer Prevention. - 2012. No. 13 (9). - P. 4393-4402.

20. Targeting free radicals in oxidative stress-related human diseases / P. Poprac, K. Jomova, M. Simunkova [et al.] // Trends Pharmacol. Sci. - 2017. - No. 38 (7). P. 592-607.

21. Mandal P. Potential biomarkers associated with oxidative stress for risk assessment of colorectal cancer / P. Mandal // Naunyn Schmiedebergs Arch. Pharmacol. 2017. - No. 390 (6). - P. 557-565.

\section{REFERENCES}

1. Bray, F., Ferlay, J., Soerjomataram, I., Siegel, R., Torre, L., \& Jemal, A. (2018). Global cancer statistics 2018: Globocan estimates of incidence and mortality worldwide for 36 cancers in 185 countries. CA Cancer J. Clin., 68, 394-424.

2. Arigesavan, K., \& Sudhandiran, G. (2015). Carvacrol exhibits anti-oxidant and anti-inflammatory effects against 1, 2-dimethyl hydrazine plus dextran sodium sulfate induced inflammation associated carcinogenicity in the colon of Fischer 344 rats. Biochem. Biophys. Res. Communю, 461 (2), 314-320.

3. Hamiza, O.O., Rehman, M.U., \& Tahir, M. (2012). Amelioration of 1,2 dimethylhydrazine (DMH) induced colon oxidative stress, inflammation and tumor promotion response by tannic acid in Wistar rats. Asian Pacific Journal of Cancer Prevention, 13 (9), 4393-4402.

4. Mikhalovsky, S.V. Sandeman, S.R., Howell, C.A., Phillips, G.J., \& Nikolaev, V.G. (2012). Biomedical appli- cations of carbon adsorbents. In Novel Carbon Adsorbents, 21, 639-669.

5. Nikolaev, V.G. Sakhno, L.A., \& Snezhkova, E.A. (2011). Carbon adsorbents in oncology: achievements and perspectives. Exp. Oncol., 33, 2-8.

6. Madsen, M.L., Due, H., Ejskjær, N., Jensen, P., Madsen, J., \& Dybkær, K. (2019). Aspects of Vincristineinduced neuropathy in hematologic malignancies: A systematic review. Cancer Chemother. Pharmacol., 84, 471-485.

7. Kozhemiakin, Yu.M., Khromov, O.S., Filonenko, M.A., \& Saifetdinova, H.A. (2002). Naukovo-praktychni rekomen- datsii z utrymannia laboratornykh tvaryn ta roboty $z$ nymy [Scientific and practical recommendations for the mainte- nance of laboratory animals and work with them]. Kyiv: Avitsena [in Ukrainian].

8. Deryagina, V.P., Ryzhova, N.I., \& Razin, A.N. (2009). Eksperimentalnoye izucheniye deystviya Lenti- 
nusEdodes (Shiitake) na rost opukholi u myshey na modelyakh trans plantatsionnogo i khimicheskogo kantserogeneza [Experimental study of the effect of LentinusEdodes (Shiitake) on tumor growth in mice on models of transplantation and chemical carcinogenesis]. Rossiyskiy onkologicheskiy zhurnal - Russian Journal of Oncology, 1, 33-38 [in Russian].

9. Rybolovlev, Yu.R., \& Rybolovlev, R.S. (1979). Dozirovaniye veshchestv dlya mlekopitayushchikh po konstantam biologicheskoy aktivnosti [Dosing of substances for mammals according to the constants of biological activity]. Doklady AN SSSR - Reports of the Academy of Sciences of the USSR, 247 (6), 1513-1516 [in Russian].

10. Dubinina, E.E., \& Pustyhina, A.V. (2008). Okislitelnaya modifikatsiya proteinov, yeye rol pripatologicheskikh sostoyaniyakh [Oxidative modification of proteins, its role in pathological conditions]. Ukr. biokhim. zhurn. - Ukrainian Biochemical Journal, 80 (6), 5-18 [in Russian].

11. Lushchak, V.I., Bahniukova, T.V. \& Lushchak, O.V. (2004). Pokaznyky oksydatyvnoho stresu. Tiobarbituraktyvni produkty i karbonilni hrupy bilkiv [Indicators of oxi- dative stress. Thiobarbiturative products and carbonyl groups of proteins]. Ukrainskyi biokhimichnyi zhurnal Ukrainian Biochemical Journal, 76 (6), 136-141 [in Ukrainian].

12. Koroliuk, M.A., Ivanova, L.I. \& Maiorova, I.H (1988). Metod opredeleniya aktivnosti katalazy [Method for determining the activity of catalase]. Lab. Delo- Lab. Business, 1, 16-19 [in Russian].

13. Chevari, S., Chaba, I. \& Sekey, I. (1985). Rol super-oksiddismutazy $v$ okislitelnykh protsessakh kletk i metod opredeleniya yeye $v$ biologicheskikh materialakh [The role of superoxide dismutase in the oxidative processes of the cell and the method for determining it in biological materials]. Lab. delo - Lab. Business, 1, 678681 [in Russian].
14. Okeh, U. (2009). Statistical problems in medical research. East. Afr. J. Public. Health., 6 (1), 1-7.

15. Marushchak, M.I. (2012). Rol aktyvnykh form kysniu u rozvytku i prohresuvanni hostroho urazhennia lehen $v$ eksperymenti [Role of reactive oxygen species in the development and progression of acute lung injury in experiment]. Med. khimiia - Med. Chemistry, 1 (50), 104-108 [in Ukrainian].

16. Perše, M., \& Cerar, A. (2005). The dimethylhydrazine induced colorectal tumours in rat-experimental colorectal carcinogenesis. Radiology and Oncology, 39 (1), 61-70

17. Zyn, A. (2012). Prooksydantno-antyoksydantnyi homeostaz imembrannyi transportu zhyvykh orhanizmakh [Prooxidant-antioxidant homeostasis and membrane transport in living organisms]. Visnyk Lvivskoho universytetu - Bulletin of Lviv National University, 60, 21-39 [in Ukrainian].

18. Harzallah, H.J., Grayaa, R., Kharoubi, W., Maaloul, A., Hammami, M., \& Mahjoub, T. (2012). Thymoquinone, the Nigella sativa bioactive compound, prevents circulatory oxidative stress caused by 1,2-dimethylhydrazine in erythrocyte during colon postinitiation carcinogenesi. Oxid. Med. Cell Longev., 4, 1-6.

19. Hamiza, O.O., Rehman, M.U., Tahir, M., Khan, R., Khan, A.Q., Lateef, A., Ali, F., et al. (2012). Amelioration of 1,2 dmethylhydrazine $(\mathrm{DMH})$ induced colon oxidative stress, inflammation and tumor promotion response by tannic acid in Wistar rats. Asian Pacific Journal of Cancer Prevention, 13 (9), 4393-4402.

20. Poprac, P., Jomova, K., \& Simunkova, M. (2017). Targeting free radicals in oxidative stress-related human diseases. Trends Pharmacol. Sci., 38 (7), 592-607.

21. Mandal P. (2017). Potential biomarkers associated with oxidative stress for risk assessment of colorectal cancer. Naunyn Schmiedebergs Arch. Pharmacol., 390 (6), 557-565.

\section{ЭНДОГЕННАЯ ИНТОКСИКАЦИЯ У КРЫС С ЭКСПЕРИМЕНТАЛЬНЫМ КАНЦЕРОГЕНЕЗОМ ПОСЛЕ ПРИМЕНЕНИЯ ЦИТОСТАТИКА НА ФОНЕ СОРБЦИОННОЙ ТЕРАПИИ}

\section{Резюме}

Вступление. Ежегодно количество онкологических больных колоректальным раком растет. Тяжесть состояния больных довольно часто обусловлена гиперфункцией активных форм кислорода с последующим нарушением антиоксидантной защиты организма. Поэтому важным является изучение эфрфективности действия цитостатика на фоне энтеросорбционной терапии в условиях эндогенной интоксикации.

Цель исследования - оценить эфрфективность использования цитостатика "Винкристин" на фоне энтеросорбционной терапии в условиях оксидативного стресса в организме крыс, пораженных 1,2-диметилгидразином.

Методы исследования. Эксперимент выполнен на белых крысах-самцах, которым моделировали рак толстой кишки путем еженедельного подкожного введения 1,2-диметилгидразина в дозе 7,2 мг/кг массы тела в течение 30-ти недель. Энтеросорбент АУТ вводили интрагастрально ежедневно на про- 
тяжении 21-го дня после моделирования канцерогенеза в дозе 1 мл взвеси (что соответствует 0,2 г чистой массы продукта) на 100 г массы тела животного. Цитостатик "Винкристин” вводили животным с индуцированным канцерогенезом внутрижелудочно ежедневно в течение 14-ти дней в дозе 0,23 мг/кг массы тела после 21-дневной детоксикационной терапии. Развитие оксидативного стресса изучали по активности окислительной модифрикации протеинов, концентрации продуктов перекисного окисления липидов, активности супероксиддисмутазы и каталазы.

Результаты и обсуждение. Полученные результаты исследования свидетельствуют о том, что введение 1,2-диметилгидразина в течение 30-ти недель способствовало развитию оксидативного стресса. В экспериментальных животных нарушался про-антиоксидантный баланс, что сопровождалось снижением активности антиоксидантной системы. Применение энтеросорбента АУТ способствовало нормализации этих показателей, а проведенная цитостатическая терапия незначительно повлияла на активность окислительных процессов в организме подопытных животных.

Вывод. Полученные результаты указывают на отсутствие выраженного побочного эфрфекта цитостатика "Винкристин" и подтверждают положительную динамику использования детоксикационной терапии энтеросорбентом АУТ во время прогрессирующего развития оксидативного стресса в условиях смоделированного канцерогенеза.

КЛЮЧЕВЫЕ СЛОВА: оксидативный стресс; антиоксидантная система; 1,2-диметилгидразин; энтеросорбент АУТ; цитостатик "Винкристин".

O. I. Kachur, L. S. Fira, P. G. Likhatsky I. HORBACHEVSKY TERNOPIL NATIONAL MEDICAL UNIVERSITY

\section{ENDOGENIC INTOXICATION IN RATS WITH EXPERIMENTAL CARCINOGENESIS AFTER APPLICATION OF CYTOSTATICS ON THE BACKGROUND OF SORPTION THERAPY}

\section{Summary}

Introduction. Every year the number of cancer patients with colorectal cancer is growing. The severity of the condition of patients is often due to hyperfunction of reactive oxygen species with subsequent violation of the body's antioxidant defenses. Therefore, it is important to study the effectiveness of cytostatics on the background of enterosorption therapy in conditions of endogenous intoxication.

The aim of the study - to evaluate the effectiveness of the use of the cytostatic Vincristine on the background of enterosorption therapy under conditions of oxidative stress in the body of rats affected by 1,2-dimethylhydrazine

Research Methods. The experiments were performed on white male rats simulated for colon cancer by weekly subcutaneous administration of 1,2-dimethylhydrazine at a dose of $7.2 \mathrm{mg} / \mathrm{kg}$ body weight for 30 weeks. Enterosorbent AUT was administered intragastrically daily for 21 days after modeling carcinogenesis at a dose of $1 \mathrm{ml}$ of suspension (corresponding to $0.2 \mathrm{~g}$ of net weight of the drug) per $100 \mathrm{~g}$ of body weight of the animal. The cytostatic Vincristine was administered intragastrically daily to animals with induced carcinogenesis after 21 days of detoxification therapy for 14 days at a dose of $0.23 \mathrm{mg} / \mathrm{kg}$ body weight. The development of oxidative stress was studied by the activity of oxidative modification of proteins (OMB), the concentration of lipid peroxidation products (LPO) by the activity of superoxide dismutase (SOD), catalase.

Results and Discussion. The results of the study indicate that a 30-week administration of the xenobiotic 1,2DMG promotes the development of oxidative stress. In experimental animals, the peroxidant and antioxidant balance is disturbed, which is accompanied by a decrease in the antioxidant system. The use of enterosorbent AUT contributed to the normalization of these parameters, and the cytostatic therapy had a negligible effect on the course of oxidative processes in the body of experimental animals.

Conclusion. The obtained results indicate the absence of a pronounced side effect of the cytostatic Vincristine and confirm the positive dynamics of the use of detoxification therapy with AUR sorbent during the progressive development of oxidative stress under the conditions of simulated carcinogenesis.

KEY WORDS: oxidative stress; antioxidant system; dimethylhydrazine; enterosorbent AUT; cytostatic Vincristine.

Отримано 20.05.20

Адреса для листування: Л. С. Фіра, Тернопільський національний медичний університет імені І. Я. Горбачевського мОз України, майдан Волі, 1, Тернопіль, 46001, Україна, e-mail: firals@tdmu.edu.ua. 